evidently less important "high momentum droplets," which infect "by direct implantation on to the vaginal introitus."

A mask consisting of four layers of fine dental gauze or eight double layers of surgical gauze arrested both types of droplets, but half that thickness increased the amount of dangerous low momentum spray. The inclusion of a "snout" in the design and secure fastening below the chin reduced the risks of down flow and the escape of droplets at the sides of the mask. Paradoxically, saturation of the mask increased its efficiency but also increased the danger of indirect transfer from the sodden material.

During the past two decades the reusable natural fabric mask has been replaced in operating theatres by disposable synthetic types, usually incorporating an efficient fibreglass or plastic filter. ${ }^{10}{ }^{11}$ Cheaper disposable paper masks are very satisfactory when used for short periods, however-for example, in the protective isolation of highly susceptible patients ${ }^{12}$ and during procedures such as lumbar puncture, inserting intravenous lines, and dressing large wounds. ${ }^{11}$ They should also prove adequate during routine vaginal delivery.

Nevertheless, if the obstetricians' luck holds, their facemasks will tend to go the way of the traditional preparatory enema ${ }^{13}$ and shaving the pubis. ${ }^{14}$ The clinical microbiologist must, however, view with serious misgivings this latest example of iconoclasm by his colleagues.

SYDNEY SELWYN

Professor of Medical Microbiology,

Charing Cross and Westminster Medical School,

London SWIP 2AR

1 Selwyn S. Skin preparation, the surgical 'scrub' and related rituals. In: Karran S, ed. Controversies in surgical sepsis. Eastbourne and New York: Praeger, 1980:23-32.

Lidwell OM, Lowbury EJL, Whyte W, Blowers R, Stanley SJ, Lowe D. Effect of ultraclean air in operating rooms on deep sepsis in the joint after total hip or knee replacement; a randomised

study. Br Med $\mathcal{F} 1982 ; 285: 10-4$.
3 Mackintosh CA. A testing time for gowns? $\mathcal{F}$ Hosp Infect 1982;3:5-8.

4 Turner MJ, Crowley P, MacDonald D. The unmasking of delivery room routine. Fournal of Obstetrics and Gynaecology 1984;4:188-90.

5 Gordon A. A treatise on the epidemic puerperal fever of Aberdeen. London: Robinson, 1795.

Hope-Simpson RE. Streptococcus pyogenes in the throat: a study in a small population, 1962 1975. F Hyg (Camb) 1981;87:109-29.

Anonymous. Puerperal streptococcal infection [Epidemiology]. Br Med f 1969;iii:788. Easmon CSF. What is the risk of beta-haemolytic streptococcal infection in obstetrics? discussion

9 Paine CG. The aetiology of puerperal infection with special reference to droplet infection. Br Med f 1935 ;i:243-6.

10 Quesnel LB. The efficiency of surgical masks of varying design and composition. $\operatorname{Br} \mathcal{F}$ Surg 1975;62:936-40.

1 Rogers KB. Face masks: which, when, where and why? J Hosp Infect 1981;2:1-4

12 Selwyn S. Protective isolation: what are our priorities? F Hosp Infect 1980;1:5-9.

3 Romney ML, Gordon H. Is your enema really necessary? Br Med J 1981;282:1269-71.

Romney ML. Pre-delivery shaving: an unjustified assault. Fournal of Obstetrics and Gynaecology

\section{Slow release theophyllines and chronic bronchitis}

Liquid concoctions containing methylxanthine have been used for asthma and bronchitis for over 100 years, and strong coffee has been shown to be an effective bronchodilator. ${ }^{1}$ The systematic investigation of methylxanthines as bronchodilators began in the $1930 s,{ }^{2}$ but they have become widely popular in Britain only in the past few years with the development of sustained release theophylline preparations. ${ }^{34}$ The benefits that come from theophylline have to be balanced against possible difficulties, ${ }^{56}$ especially in patients with asthma, and these hazards may be even greater in patients with chronic bronchitis with airflow obstruction. Theophylline has several drawbacks that result from its pharmacological features-not only its narrow therapeutic margin $^{78}$ but its variable pharmacokinetics among in- dividuals ${ }^{910}$ and the fact that saturable pathways may be affected by dietary methylxanthines. ${ }^{11} 12$ Furthermore, the clearance of theophylline may be affected by age, smoking, cor pulmonale, respiratory viral infections, impaired liver function, and erythromycin. ${ }^{13-18}$

These six factors are frequently present in patients with chronic obstructive bronchitis, for whom the oral methylxanthines appear to be widely prescribed. Their efficacy in such patients is controversial. Possible short term improvements have been reported as measured by spirometry, ${ }^{19}$ but these have not always been found in long term treatment.$^{20} \mathrm{In}$ one study a small but statistically highly significant improvement in the 12 minute walking test ${ }^{21}$ was produced with a single dose of slow release aminophylline (450 mg Phyllocontin), but $4 \mathrm{mg}$ salbutamol produced an identical response. ${ }^{22}$ The simultaneous administration of the two drugs produced a further spirometric improvement but did not affect the exercise tolerance. Surprisingly, no such improvement in exercise performance or indeed breathlessness was seen in patients with chronic obstructive bronchitis treated for a week with placebo or low dose or high dose oral theophylline, despite improvements on spirometric assessment. ${ }^{23}$ In patients with severe airflow obstruction diaphragmatic fatigue may well be a factor in the development of respiratory failure, and theophylline may improve diaphragmatic contractility, ${ }^{24}$ but the clinical importance of the effect of methylxanthines on diaphragmatic function is disputed. ${ }^{25}$

The paper by D W V Evans ( $p$ 1649) may, therefore, be an important contribution. Evans investigated the response to dosages of slow release theophylline given as a single daily dose at 2200 hours of 20 patients with chronic obstructive bronchitis (14 were considered to have accompanying emphysema based on abnormally low diffusion coefficients; $\mathrm{KCO}<68 \%$ predicted). Dosages from 200 to $800 \mathrm{mg}$ a day were given, though in four patients the highest dose was omitted because lower doses (given acutely) were intolerable. Twelve hours after the dose of oral theophylline (Uniphyllin) or placebo was given measurements were made of the peak expiratory flow rate, the forced expiratory volume in one second, the forced vital capacity, the heart rate, and the plasma concentration of theophylline. Patients also carried out a six minute corridor walk..$^{26}$ Their breathlessness was assessed by a visual analogue scale and spirometry, and the walking test was then repeated one hour later. Theophylline produced no improvement in the formal respiratory function tests-but this was not necessarily to be expected in Evans's patients, for patients who responded to an unspecified dose of an inhaled $\beta_{2}$ selective agent had been excluded from the study. Patients with severe airflow obstruction frequently need high doses of inhaled $\beta_{2}$ stimulants to achieve any substantial bronchodilatation, ${ }^{27}$ and the forced or residual vital capacities may be more appropriate measurements for assessing response to bronchodilators. Furthermore, unless the patient shows a bronchodilator response to salbutamol alone theophylline will rarely produce a response, but if he does respond to salbutamol there may be an additional bronchodilator effect of theophylline. ${ }^{28}$ Evans showed a correlation between the dose of theophylline and its plasma concentrations. He found no correlation between dosage and improvement in walking distance, and no subjective reduction in the degree of breathlessness assessed by visual analogue score. The higher drug dosages achieved plasma concentrations in the higher therapeutic range. Treatment with placebo achieved an improvement $(7 \% ; 21$ metres) in walking distance, and the study design suggested that this was not a 
training effect. (One patient, however, appeared to be on active treatment at the time of the placebo study.) This improvement in walking distance with placebo was similar to that found by Leitch and his colleagues with oral aminophylline. ${ }^{22}$ Nietrzeba and his colleagues, who used intravenous aminophylline, showed a similar improvement in maximum work in a group of patients with chronic obstructive bronchitis (unfortunately, there was no placebo study), but they failed to show any improvement in forced expiratory volume in one second or peak expiratory flow rate to either aminophylline or inhaled isoetharine $(0.68 \mathrm{mg}){ }^{29}$ They did show, however, an improvement in maximal inspiratory flow rate.

Most of these studies have been based on single dose administration of methylxanthines or selective $\beta$ stimulants rather than on maintenance treatment. In the United States theophylline is still the most common first line drug and is regularly used as maintenance treatment, but even there symptomatic benefit has been difficult to confirm. ${ }^{23}{ }^{303}$ In this study, however, the improvement in spirometry and inspiratory flow rate with theophylline was only two thirds that achieved with $\beta$ stimulants. ${ }^{\text {30a }}$

Passamonte and Martinez compared the spirometric response to inhaled $\beta$ stimulants and atropine sulphate in patients with chronic obstructive bronchitis who were already stabilised on high maintenance doses of theophylline. ${ }^{31}$ Their results showed that theophylline alone was not providing maximal bronchodilatation. Unfortunately, as noted by Niewoehner and Leatherman, ${ }^{32}$ this study did not investigate whether theophylline was necessary to achieve maximal bronchodilatation; these commentators also suggested that the highly favourable therapeutic index of inhaled $\beta$ agonists gives a greater assurance of efficacy and safety and should be first line treatment.

Evans concludes that the indiscriminate use of oral methylxanthines for chronic bronchitis seems difficult to justify, and these conclusions seem reasonable: the clinical advantages appear small and the possible dangers great. ${ }^{33}$ Nineteen of 21 patients with theophylline intoxication studied by Mountain and Neff had chronic obstructive bronchitis. ${ }^{33}$ Toxic effects were serious and included grand mal seizures and were caused by confusion by the patient on the dose prescribed, excessive drug prescription by the physician, and unrecognised theophylline interactions with other drugssimilar findings to the Brompton Hospital experience for a predominantly asthmatic population.

Most patients with chronic obstructive bronchitis would be better served by first determining the dose of inhaled bronchodilator that achieves maximum bronchodilator and symptomatic effect both acutely and with maintenance treatment. ${ }^{34}$ Higher doses of $\beta$ agonists have been shown in long term studies to give subjective relief to patients with chronic bronchitis ${ }^{35}$ and some patients with severe emphysema, ${ }^{36}$ but angina may be accounted as a rare problem. ${ }^{37}$ If symptoms persist a trial of theophylline is indicated, using an incremental dosage regimen to avoid the initial side effects, and monitoring plasma concentrations carefully to avoid dangerous plasma concentrations of theo- phylline, though these methods are not perfect. ${ }^{33}{ }^{38}$ Ideally theophylline should be given double blind with placebomany trials have shown obvious placebo effects. Methylxanthines may be useful in chronic obstructive bronchitis, but the narrow safety margins suggest that they should not be first line treatment and that inhaled $\beta_{2}$ selective stimulants and inhaled anticholinergics should be used first.

\section{G M COCHRANE}

Consultant Physician in Respiratory Medicine,

Guy's and New Cross Hospitals,

London SE14 5ER

1 Becker AS, Simons KJ, Gillespie CA, Simons FER. The bronchodilator effects and pharmacokinetics of caffeine in asthma. $N$ Engl $\mathcal{Y}$ Med 1984;310:743-6.

2 Herman G, Aynesworth MB, Martin J. Successful treatment of persistent disproven "status asthmaticus." I Lab Clin Med 1937;23:135-48

Weinberger M, Hendeles L, Bighley L. The relation of product formulation to absorption of oral theophylline. N Engl f Med 1978;299:852-7.

Spangles DL, Kaloff DD, Witty HJ. Theophylline bio-availability following oral administration of six sustained-release preparations. Ann Allergy 1978;40:6-11. Woodcock AA, Johnson MA, Gedde
toxicity. Lancet 1983;ii:610-2.

6 Anonymous. Theophylline benefits and difficulties [Editorial]. Lancet 1983;ii:607-8.

Jenne JW, W yze E, Rood FS, MacDonald FH. Pharmacokinetics of theophylline. Applications to adjustment of the clinical dose of aminophylline. Clin Pharmacol Ther 1972;13:349-60. Tattersfield AE. Bronchodilators in the prevention of asthma. In: Clark TJH, Cochrane GM, eds. Bronchodilator therapy, Adis Press, 1984.

9 Prior JG, Berry D, Cochrane GM. Serum theophylline concentrations during multiple dosing with two sustained release methylxanthine preparations in normal subjects. Postgrad Med $\mathcal{F} 1980$;

10 Hendeles L, Weinberger MM, Bighley L. Disposition of theophylline following a single intravenous aminophylline infusion. Am Rev Respir Dis 1978;118:97-103

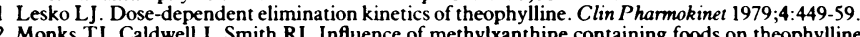
metabolism and kinetics. Clin Pharmacol Ther 1979;26:513-24.

13 Jusko WJ, Kroup JR, Vance JW, Schentag JJ, Kuritzky P. Intravenous theophylline therapy: nomogram guidelines. Ann Intern Med 1979;88:400-4.

14 Powell JR, Thiercelin JF, Vozeh S, Sansom L, Riegelman S. The influence of cigarette smoking and sex on theophylline disposition. Am Rev Respir Dis 1977;116:17-23.

15 Vicua M, McNay JL, Ludden TH, Schwertnes H. Impaired theophylline clearance in patients

with cor pulmonale. Br f Clin Pharmacol 1979;7:33-7.
16 Kozak PP, Cummins LH, Gillman SA. Administration of erythromycin to patients on theophylline.

7 Allergy Clin Immunol 1977;60:149-51. Altered theophylline pharmacokinetics during acute
Chang KC, Bell TD, Lauer BA, Chai H. Aler Piafsky KM, Sitar DS, Rangno RE, Ogilvie RI. Theophylline disposition in patients with hepatic cirrhosis. N Engl f Med 1977;296:1495-7.
M M

9 Eaton ML, Green BA, Church TR, McGowan T, Niewoehner DE. Efficacy of theophylline in "irreversible" airflow obstruction. Ann Intern Med 1980;92:758-61.

20 Jenkins PF, White JP, Jariwalla AJ, Anderson S, Campbell IA. A controlled study of slow release theophylline and aminophylline in patients with chronic bronchitis. Br $\mathcal{O}$ Dis Chest 1982;76: $57-60$.

21 McGavin CR, Gupta SP, McHardy GJR. Twelve minute walking test for assessing disability in chronic bronchitis. Br Med I 1976;i:822-3.

22 Leitch AC, Morgan A, Ellis DA, Bell G, Haslett C, McHardy GJR. Effect of oral salbutamol and slow release aminophvlline on exercise tolerance in chronic bronchitis. Thorax 1981;36:787-9. aton ML, MacDonald FM, Church TR, Niewoehner DE. Effects of theophylline on breathlessness and exercise tolerance in patients with chronic airflow obstruction. Chest 1982;82:538-42.
Aubier MA, De Troyer A, Sampson M, Macklem PT, Roussos L. Aminophylline improves diaphragmatic contractility. $N$ Engl f Med 1981;305:249-52.

25 Moxham J. Respiratory muscle fatigue-aspects of detection and treatment. Bull Eur Physiopathol Respir 1984;20:437-44.

26 Butland RJA, Pang J, Cross ER, Woodcock AA, Geddes DM. Two, six, and 12 minute walking tests in respiratory disease. Br Med $\mathcal{F} 1982 ; 284: 1607-8$.

7 Prior JG, Nowell RV, Cochrane GM. High dose inhaled terbutaline in the management of chronic severe asthma: comparison of wet nebulisation and tube spacer delivery. Thorax 1982;37:300-3. Barclay J, Whiting B, Meredith PA, Addis JG. Theophylline-salbutamol interaction bronchodilator response to salbutamol at

29 Nietrzeba RM, Elliott CG, Adams TD, Yeh MP, Yanowitig FG. Effects of aminophylline upon exercise performance of patients with stable chronic airflow obstruction. Bull Eur Physiopathol
Respir 1984;20:361-7.

30 Alexander MR, Dull WL, Dasch JE. Treatment of chronic obstructive pulmonary disease with

30a Jenne JW, Siever JR, Druz NS, Solaro JV, Cohen SM, Sharp JT. The effect of maintenance theophylline therapy on lung work in severe chronic obstructive pulmonary disease while standing and walking. Am Rev Respir Dis 1984;230:600-5.

31 Passamonte PM, Martinez AJ. Effect of inhaled atropine or metaproterenol in patients with chronic airway obstruction and therapeutic serum theophylline levels. Chest 1984;85:610-5. Niewoehner DE, Leatherman JW. Bronchodilator therapy in chronic airflow obstruction. Chest
$1984 ; 86: 161-2$.

33 Jenne JW, Siever JR, Druz NS, Solaro JV, Cohen SM, Sharp JT. The effect of maintenance theophylline therapy on lung work in severe chronic obstructive pulmonary disease while standing and walking. Am Rev Respir Dis 1984;130:600-5. chronic asthma: the use of simple cumulative dose-response curves. Br $\mathcal{Y}$ Dis Chest 1982;72: 266-8.

35 Andersson L, Boèthius G. Effect of domiciliary treatment with nebulised beta stimulants-a retrospective follow-up of 102 patients. Eur $\mathcal{F}$ Respir Dis 1984;65(suppl 136):205-12. Connellan SJ, Wilson RSE. The use of domiciliary nebulised salbutamol in the treatment of severe

emphysema. Br $\mathcal{F}$ Clin Pract 1979;33:135-6.
Neville E, Corris PA, Vivian J, Nariman S, Gibson GJ. Nebulised salbutamol and angina. BrMed $\mathcal{F}$ 1982;285:849-50.

ndeles $L$, Lafrate $P$, Weinberger $M$. A clinical and pharmacokinetic basis for the selection and use of slow release theophylline. Clin Pharmacokinet 1984;9:95-135. 